\title{
IV.-Azo-derivatives of 4-Methyl-a-naphthocoumarin.
}

By John Theodore Hewitt and Herbert Victor Mitchell.

IN continuation of earlier work on azocoumarins containing the azogroup in the para-position with respect to the lactonic oxygen (Mitchell, Trans., 1905, 87, 1229), it has been considered advisable to examine representatives of the naphthalene series. Whilst benzeneazophenol cannot be directly prepared from quinone and phenylhydrazine, benzeneazo- $\alpha$-naphthol was obtained by Zincke and Bindewald (Ber., 1884, 17, 3026) by the interaction of phenylhydrazine and a-naphthoquinone. Further support for the formulation of benzeneazo- $a$-naphthol as $a$-naphthoquinonehydrazone is afforded by the reaction between this substance and tetramethyldiaminobenzhydrol discovered by Möhlau and Kegel (Ber., 1900, 33, 2858).

As a convenient substance for our experiments, we have chosen the 4-methyl-a-naphthocoumarin obtained by Bartsch, who condensed a-naphthol with ethyl acetoacetate (Ber., 1903, 36, 1966).

Benzeneazo-4-methyl-a-naphthocoumarin,

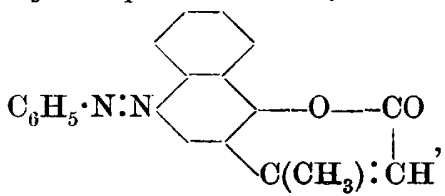

was obtained by the action of phenyldiazonium chloride on a solution VOL. LXXXIX. 
of potassium 4-methylnaphthocoumarinate. The colour of the alkaline solution produced is intensely red, and, on addition of dilute sulphuric acid, the azocoumarin is deposited as a scarlet precipitate. By recrystallisation from pyridine, orange-brown, long, flaky needles are obtained, which melt at $207^{\circ}$. The substance is also soluble in chloroform and alcohol, but is insoluble in light petroleum.

0.0911 gave $0.2553 \mathrm{CO}_{2}$ and $0.0363 \mathrm{H}_{2} \mathrm{O} . \mathrm{C}=76 \cdot 4 ; \mathrm{H}=4 \cdot 4$. $\mathrm{C}_{20} \mathrm{H}_{14} \mathrm{O}_{2} \mathrm{~N}_{2}$ requires $\mathrm{C}=76.4 ; \mathrm{H}=4.5$ per cent.

o-Nitrobenzeneazo-4-methyl-a-naphthocoumarin was obtained from diazotised $o$-nitroaniline in the usual manner; the alkaline solution is reddish-violet. The azocoumarin crystallises from pyridine in small, brown flakes melting at $268^{\circ}$.

$0 \cdot 1274$ gave $13 \cdot 6$ c.c. nitrogen at $20^{\circ}$ and $763 \mathrm{~mm}$. $\mathrm{N}=12 \cdot 1$. $\mathrm{C}_{20} \mathrm{H}_{13} \mathrm{O}_{4} \mathrm{~N}_{3}$ requires $\mathrm{N}=11.8$ per cent.

The substance dissolves in chloroform, less readily in alcohol, and is insoluble in light petroleum.

$\mathrm{m}$-Nitrobenzeneazo-4-methyl-a-naphthocoumarin gives alkaline solutions possessing a colour similar to that of cobalt nitrate, although not blue in shade. On crystallisation from chloroform, light brown needles are obtained which melt at $239^{\circ}$. Whilst soluble in pyridine, the substance is nearly insoluble in alcohol.

0.1224 gave $0.3004 \mathrm{CO}_{2}$ and $0.0426 \mathrm{H}_{2} \mathrm{O}$. $\mathrm{C}=66.9 ; \mathrm{H}=3.8$. $\mathrm{C}_{20} \mathrm{H}_{13} \mathrm{O}_{4} \mathrm{~N}_{3}$ requires $\mathrm{C}=66.9 ; \mathrm{H}=3.6$ per cent.

p-Nitrobenzeneazo-4-methyl-a-naphthocoumarin is remarkable, in that its alkaline solutions are indigo-blue in colour. On acidifying the alkaline solution, the azocoumarin is precipitated as a reddish-brown powder which, when recrystallised from toluene, melts at $270-271^{\circ}$.

$$
\begin{gathered}
0.1170 \text { gave } 0.2886 \mathrm{CO}_{2} \text { and } 0.0393 \mathrm{H}_{2} \mathrm{O} . \quad \mathrm{C}=67.3 ; \mathrm{H}=3.7 . \\
\mathrm{C}_{20} \mathrm{H}_{13} \mathrm{O}_{4} \mathrm{~N}_{3} \text { requires } \mathrm{C}=66.9 ; \mathrm{H}=3.6 \text { per cent. }
\end{gathered}
$$

The substance dissolves fairly readily in toluene, and only sparingly in alcohol; it is gradually dissolved by solutions of hot alkalis with production of the indigo coloration. So extremely marked is the coloration that it seems advisable to inquire into the cause, especially in view of the fact that the $p$-nitrobenzene-4-azo-a-naphthol discovered by Bamberger (Ber., 1895, 28, 848; compare Hantzsch, ibid., 28, 1124), although brownish-red in colour, gives violet alkaline solutions. Such difference in colour between an azophenol and its alkali salts only seems to occur when a nitro-group is present in the substituent arylazo-group in the para-position.

We therefore prepared a specimen of $p$ nitrobenzene-4-azo-a-naph- 
thol-2-carboxylic acid, which, itself brown in colour, dissolved in alkalis with a bluish-violet shade. If the colour were merely due to salt formation, one would expect the colouring matter to give a violet colour with an aluminium mordant. The colour obtained was, however, brown, and since the lake obtained must contain the

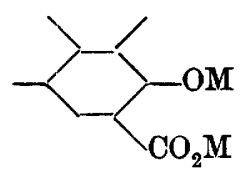

grouping, one is inclined to assign another formula to the violet alkaline salts. The only apparent alternative is to assume the formation of an isonitro-group under the influence of alkali, which would, for instance, mean that the potassium salt of $p$-nitrobenzeneazo- $\alpha$ naphthol must possess the constitution :

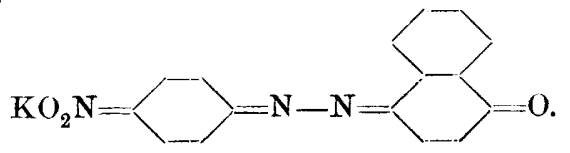

East London Coliege. 